\title{
Agritourism: A Possible Alternative to Zimbabwe’s Tourism Product?
}

\author{
Oliver Chikuta \\ Chinhoyi University of Technology, Chinhoyi, Zimbabwe \\ Caroliny Makacha \\ Midlands State University, Gweru, Zimbabwe
}

\begin{abstract}
This study sought to establish whether agritourism can be an alternative to Zimbabwe's tourism product or not. Of essence were the potential and possible challenges to be faced in developing the concept. An exploratory research design was adopted since agritourism is a relatively new concept in Zimbabwe. Data were collected through a detailed interviewer-administered questionnaire. Farmers and farm managers were the target respondents. In addition, a thirty-minute interview was conducted with an executive at the Zimbabwe Tourism Authority's (ZTA) Department of Market Research and New Product Development. Observations were also made in order to fortify the data collected through questionnaires. The results show that agritourism can be a viable option since some resources already exist in a number of farms. Challenges were noted and these need to be acted upon by the relevant authorities, that is, the Ministry of Tourism and Hospitality Industry and the ZTA.
\end{abstract}

Keywords: agritourism, potential, challenges, Zimbabwe

\section{Introduction}

There is a growing market demand for non-urban vacation experiences which has stimulated interest in travel to natural and rural environments. Agritourism has come about as a result of the curiosity about farming heritage and lifestyles and a search for less commercialised and inexpensive vacation alternatives (Blacka, Couture, Coale, Dooley, Hankins, Lastovica, ..., \& Uysal, 2001). Agritourism can also be used as a way of sustaining the economy of the hinterland and giving city dwellers a rural experience. Most of the researches regarding agritourism have been conducted in the developed world where the concept is well developed and implemented.

Within the European Union, agritourism is considered to be crucial to allaying mass outmigration and economic decline and this has led to drafting and implementation of appropriate policies to support its development (Hegarty \& Przezborska, 2005). The researchers have noted that little research regarding agritourism have been done in the developing world despite the potential benefits it brings to communities, regions, or countries. The Italian National Law has identified goals for agritourism which include: halting rural outmigration by keeping farmers on the land, improving the utilisation of both natural and built rural resources, enhancing environmental conservation and management, promotion of "typical" rural products, supporting rural traditions and cultural initiatives, developing agricultural areas, developing youth and social tourism, and enhancing the relationship between the city and the countryside (Sonnino, 2004).

Oliver Chikuta, Dean-School of Hospitality and Tourism, Chinhoyi University of Technology. Email: chikutao@gmail.com. Caroliny Makacha, Lecturer, Department of Tourism and Hospitality Management, Midlands State University. 
In Zimbabwe, agriculture is the mainstay of the economy contributing between $11 \%$ and $14 \%$ of GDP and accounting for $60 \%$ of the raw materials that are required by the manufacturing and processing sectors (Maiyaki, 2010). It also provides $45 \%$ of the country's exports, providing employment for $70 \%$ of Zimbabwe's population (Weiner, Moyo, Munslow, \& O’Keefe, 1985; Maiyaki, 2010). The agricultural land is divided into five main agro-ecological regions which relate to climatic conditions, soils, and to the appropriate farming systems adopted. Quality of the land declines from natural region 1 through 5 (Mutisi, 2009), with region one receiving precipitation above $900 \mathrm{~mm}$ characterised by high altitude, steep slopes, and low temperatures. The least is region five that is characterised by erratic rainfall pattern averaging less than $450 \mathrm{~mm}$ per year. On the other hand, tourism currently contributes $4.5 \%$ to the country's GDP and contributes significantly to employment as well as exports (Zimbabwe Tourism Authority [ZTA], 2012). It is therefore the thrust of this research to answer the questions: What is the potential for agritourism development in Zimbabwe? What are the likely challenges? How can the challenges be dealt with?

\section{Background}

\section{Tourism in Zimbabwe}

Tourism was the fastest growing economic sector in Zimbabwe after independence in 1980 and it experienced a growth from 20\% to 40\% between 1980 and 1999 (ZTA, 2007). Between these years, it also contributed 8\% to GDP. Tourism reached its peak in 1999 with arrivals being about 2.1 million. This also had a positive contribution to revenue which was around US\$700m (ZTA, 2009). However, tourism started to decline in the year 2000 due to events that have been associated with accelerated land reform which include political instability, negative publicity towards the country, and the economic recession that the country experienced (Karambakuwa, Shonhiwa, Murombo, Mauchi, Gopo, Denhere, ..., \& Mudavanhu, 2011). The country is well known for the majestic Victoria Falls and most of the marketing efforts are directed to this spectacular attraction. This was especially true during the period of economic turmoil when the country was trying to find ways of getting the precious foreign currency. Songs were even composed and sang about the Victoria Falls and the ZTA produced a DVD titled "Go to Victoria Falls.com". For the tourist who has visited Zimbabwe before, the continued talk about the Victoria Falls does not give any impetus for coming back. Apart from the Victoria Falls, much talk was also about the Great Zimbabwe, Kariba, and the Eastern highlands. The continued talk of the very same attractions day in day out led others to conclude that Zimbabwe's tourism product was tired and there is nothing else to offer. The researchers therefore felt that there is a need to develop alternative products that will contribute positively to tourist arrivals which have been on the recovery path due to the positive image that has been built by the ZTA's perception management program. Among the possible alternative products is agritourism.

\section{Agritourism Defined}

Many terms have been used to convey the idea of agritourism. These terms include agricultural tourism, agro tourism, farm tourism, farm vacation tourism, wine tourism, and agri-entertainment (McCullough, Brandt, \& Rhoades, 2008; Busby \& Rendle, 2000). Generally, these terms refer to small-scale farm enterprises and community ventures that showcase the activities and produce of rural families and the agricultural heritage of the farming regions to travellers. The combination of the prefix agri and the noun tourism resulted in the formation of a new word that means tourists activity whose aim is to familiarise oneself with farming activity and recreation in an agricultural environment (Sznajder, Przezborska, \& Scrimgeour, 2009). However, it should 
be noted that farm vacation tourism is not the same as agritourism but is a segment within the realm of agritourism that includes only the accommodations sector of tourism (Mcgehee \& Kim, 2004; Pizam \& Poleka, 1980; Weaver \& Fennell, 1997).

Agritourism, just like any other terms in tourism, is fraught with definitional confusions. It has been defined by Beall (1996) as an alternative farming enterprise that is a business conducted by a farm operator for the enjoyment and education of the public to promote the products of the farm and thereby generate additional farm income. On the other hand, Mcgehee and Kim (2004) articulated that agritourism is understood differently by tourists and providers of agritourist services. For a tourist, agritourism means familiarizing oneself with agricultural production or recreation in the agricultural environment or it may include an opportunity to help with farming tasks during the visit. However, one definition that has been adopted by many scholars is that it is the act of visiting a working farm or any agricultural, horticultural, or agribusiness operation for the purpose of enjoyment, education, or involvement in the activities of the farm operation (Colton \& Bissix, 2005). The researchers adopted the definition by Colton and Bissix (2005). In addition, from an agricultural perspective, tourism is defined as the selling of agriculture products and services to the travellers or agritourists. Agritourism overlaps with ecotourism and culinary tourism (Rilla, 1997). These definitions show a common theme that combines elements of farm life and the tourism industry. Some characteristics can be derived that underpin the concept of agritourism (Phillip, Hunter, \& Blackstock, 2010). These include the following: working/operational farm and contact with agricultural activity.

Working/operational farm. This is the most frequently cited requirement associated with agritourism. The term working farm is used to signify a farm where agriculture is currently being practised (Iakovidou, 1997). However, Clarke (1996) illustrated the fluidity of characteristics used to define a working farm with aspects such as the physical area of land, proportion of agricultural income, and individuals' expertise and motivations being the most cited.

Contact with agricultural activity. By being based on a working farm, tourism implicitly comes into some form of contact with agriculture in terms of a shared physical environment. However, the level of contact tourists have with agricultural activities varies considerably (Phillip et al., 2010). The contact can be direct, for example, harvesting fruits or milking cows, indirect contact can occur in food processing, and finally is the passive contact which revolves around outdoor activities. It should be noted that there must be a direct connection between tourism and the agrarian environment (R. Sharpley \& J. Sharpley, 1997). The connection is sometimes expressed in terms of the two being intertwined (Gladstone \& Morris, 2000). The analysis of the definitions of agritourism shows that its objective involves having members of the public coming to a farm with the ultimate goal being to increase farm income by providing fee-based education to the client.

\section{An Overview of Agritourism}

The concept of agritourism has been successfully developed in Europe and South America since the 1970s and it attracts large numbers of tourists. In USA, according to Travel Industry Association of America (TIAA), 87 million individuals have taken a trip to an agritourism destination between 1999 and 2003 (TIAA, 2004). In Australia, agritourism has become one of the most sought after "Aussie experiences”. The development of agritourism in these countries and other types of on farm enterprises has been promoted as a means to reduce the challenges that farmers experience in the sense that they can increase farm revenues and profits (Barbieri, 2010). In Africa, South Africa is one country where agritourism is being practised. It is, however, unfortunate 
that this form of tourism is still a little disorganised and there is no government support yet (Kepe, Ntsebeza, \& Pithers, 2001). The same applies with Namibia where there is evidence of some vacation farms and some agricultural shows are held at provincial and national levels (Shackley, 1993). Farms also sell their produces in roadside stands.

The history of vacation farms dates back to some hundreds of years. In USA, the concept of farm-related vacations can be traced back to the late 1800s when city folks visited farming relatives in an attempt to escape from the city's summer heat (Sznajder et al., 2009). The observation made by these authors also accords with that of Frater (1983) and Roberts (2002) who asserted that the concept of agritourism is one of the longest established forms of organized alternative tourism having been in existence in Europe as a formal industry since the late 1800s. However, the term agritourism came into existence in the late 80 s to describe anything that relies or builds on the relationship between farming and tourism.

This type of recreation is now highly commercialised and is a dynamic business sector in many parts of the world and is becoming very popular in other nations like India and Brazil (Gopal, Varma, \& Gopinathan, 2008). In Europe, the agritourism system exists in its most organized form and is highly popular. However, in the developing world, the concept has not yet been fully developed. Shackley (1993) noted that with the exception of Namibia, there is scant evidence of a formal farm-based tourism industry in the less developed world although its potential in such areas appears high. The observation by Shackley was applicable in the then 1990s though because no other country was tapping into the agritourism market.

Agritourism includes a variety of participant, educational, and spectator experiences including outdoor recreation like fishing, wildlife, photography, hunting, horseback riding, educational experiences (farm and cannery tours, cooking classes, wine tasting, cattle drives or help work in the farm/ranch), entertainment (harvest festivals or corn mazes), hospitality services (farm and ranch stays, guided tours, or outfitter services), on farm direct sales (u-pick your own operations or roadside stands) and off the farm direct sales (farmers markets, country and state fairs, special events) (Mcgehee \& Kim, 2004). These activities can be divided into three broad themes that are fixed attractions, events, or services. Agritourism is a growing industry and presents a number of opportunities for the farmers, farm owners, surrounding communities, and the tourism industry at large. Through agritourism, people can meet and understand different aspects of different cultural lifestyles, the traditional customs with positive and favourable effects on human relationship (Silvia, 2008).

Agritourism is an intensely personal business much of which is repeat and the owners feel that personal contact between tourists and the host farmers is one of the business's main attractions to visitors (Nilsson, 2002). A key feature of agritourism is the opportunity it provides for cultural exchange through personal contact. Not only does this present urban visitors with an opportunity to learn about farming practices, it also helps to reduce the isolation of many farming families. The entire concept of agritourism is based on the interpersonal, human, direct, and hospitable relations between country residents and visitors (Askelli, 2005). This is the reason why there is fostering of the contact of visitors with nature, land cultivation, fruit gathering, and local residents. In addition, tourists have become and are still becoming more sophisticated, experienced, and demanding (Clarke, 1996; Williams \& Kelly, 2001; Srikatanyoo \& Campiranon, 2010). There has been a rise of the "new tourist" who seeks an experience, not a view, a partaking in the excitement involved with any of a range of activities, not photographing only. In other words, the tourist requires to be part of the tourism destination, even for a very short time, rather than an observer and to "take it home" as an integral part of themselves. Kohler (2004) asserted that the new tourist is concerned with the "I have done it" notion rather than 
"I have seen it". Agritourism in many nations is increasingly being recognised as an important alternative farming activity that diversifies the economic base, provides educational opportunities to tourists, and provides greater community cohesion (Colton \& Bissix, 2005).

Agritourism is also a form of alternative tourism (Roberts, 2002). For it to qualify as a form of alternative tourism, agritourism should involve operations that are locally owned and derive most of their income from agriculture (Weaver, 2006). This notion is also supported by Askelli (2005) who asserted that agritourism supports and promotes local agricultural production, the manufacture, and trade of traditional products and the local culture and wealth. Sonnino (2004) articulated that at a broader level and in theory, agritourism is a sustainable strategy that promotes the conservation of a broadly conceived rural environment through its socioeconomic development. This shows that the concept of agritourism can be used to promote sustainability as few numbers of tourists visit a farm and the contact between the farmers and the tourists is high.

Some authors, however, asserted that farm-based tourism is attractive from an economic perspective because of its potential to supplement and diversify rural economies in peripheral areas (Weaver, 2006). Schmitt (2010) argued that while agritourism has become an important permanent livelihood strategy for some farming families, it remains an additional income for others. Either way, agritourism has turned out to be a source of women's growing self-confidence as well as a sustainable ingredient of regional development. This is also supported by Nickerson, Black, and McCool (2001) who asserted that there is evidence that the tourism component provides income and power for female adult household members who provide most of the relevant labour. The author goes on to say that in a survey conducted, many female participants cited contact with guests as an outlet for relieving stresses caused by social isolation.

It cannot be ruled out that agritourism is also a form of social tourism characterised by low cost as well as the contact it allows between different cultures (Nilsson, 2002; Harris, Griffin, \& Williams, 2002). In support of this notion, Weaver and Fennell (1997) suggested some traits of an agritourist and these include the fact that agritourists enjoy spending quality time with family. In addition, agritourists enjoy exploratory day trip style experiences with a country theme and they visit farms 2-6 times per year. This shows that agritourism is a form of immersing oneself with people from different backgrounds and promotes the social aspect of people.

Agritourism as compared to other forms of tourism is unique (Sznajder et al., 2009). Its uniqueness comes from the fact that it has a possibility to satisfy human need with practical participation in food production, in the life of a rural family in a rural setting. In addition, the concept also satisfies the human cognitive need with farming production or ethnography. Hence, agritourism gives the chance to learn about the lives of rural people, their culture, and customs as also articulated by Nilsson (2002). With agritourism, emotional needs are satisfied. This is "the willingness to have direct contact with domestic animals, plant and animal products and the products of processing, and the need to experience the idyllic countryside associated with the atmosphere of rusticity, silence, sounds or even smells of the countryside" (Sznajder et al., 2009, p. 7). This uniqueness is also supported by Askelli (2005) who said that visitors learn how to use a loom, to embroider, observe flora and fauna, taste wine and participate in its production process and feel the appropriate time for grape harvest.

When a farm is diversified into an agritourism venture, the farm nature will turn to operate as a supplementary, complementary, or primary enterprise (Blacka et al., 2001). All these agritourism enterprises are indispensable to protect the environment and they are considered to be of benefit to the farm business as they promote sustainable consumption and production of agricultural goods and services in the societies. 
In considering an agritourism enterprise, there is a need for a careful consideration of a host of issues that will affect its success (Agritourism India, 2010; Comen \& Foster, 2002). A set of critical success factors must be in place in order for a farm-based enterprise to be more than marginally successful. The often cited factors include location, social skills, marketing and financial enterprise among others. Although agritourism is seen by both the farming community and the governments as a diversification option for maintaining business viability, there are several challenges that obstruct the success of such business (Srikatanyoo \& Campiranon, 2010). These factors can hinder the entrance of farmers into the agritourism sector. The often sited factors include lack of management skills, little knowledge of tourism development, insufficient information in terms of customer profiles, rules and regulations, and lack of family support among others.

Some scholars like Pearce (1990) articulated that although agritourism brings about economic benefits, there is a problem of blurring of friendship and business roles between hosts and guests. In addition, rural communities cannot benefit from multiplier effects sufficiently due to the possible rate of leakages. This is because the rural communities cannot cater for the tourists without having to import some raw materials.

According to Kabarati et al.'s (2009) research done in Turkey, some revenues like the fees paid by agritourists do not go to rural areas directly but return to central government. Wilson, D. R. Fesenmaier, J. Fesenmaier, and Van Es (2001) added that as the agritourism enterprise grows, the local labour may not be enough; hence, there would be a need to employ skilled personnel of which most of them would be from outside the local community. This also leads to greater leakages from the community. On the socio-cultural arena, Lobo (2001) articulated that difficulties in dealing with people from different backgrounds can cause problems like excessive drinking, acculturation, prostitution, and corruption of the youths. This may lead to problems of conflicts between the host community and the agritourists (Pearce, 1990). Despite all these ills, it is still important to understand the positive potential contribution of agritourism to rural communities and the economy at large. Scholars have written about this important concept as it applies to the developed world but very little is known regarding the potential of this type of tourism to the economies of the less developed countries especially given the difference in settings. The scholars may have forgotten that the setup in Africa particularly south of the Sahara is quite unique and what worked for in Australia, Europe, and America may be inapplicable to Zimbabwe and other Southern African countries. This research endeavoured to explore the situation in Zimbabwe and perhaps applied it to Southern Africa where the situation is almost the same.

\section{Method}

\section{Research Design}

The researchers used the exploratory research design because the concept of agritourism in Zimbabwe is relatively new both as a field of study and in practice. This helped to generate initial insights and understanding of the agritourism concept, especially in the Zimbabwean context. In addition, it made the situation clearer and possibly set the research agenda for this field of study. This is in accordance with Beri's (2000) assertion that the purpose of exploratory research is to describe and explain a set of concepts, to explore and interpret the relationship between variables, and to build theory. In this research, both qualitative research and quantitative research were used. Qualitative research helped to develop an understanding of the respondent's views and behaviours. Quantitative research, on the other hand, helped to quantify the relationships between variables. 


\section{Sampling}

In this research, the population was made up of farmers or farm managers in the country's farming regions and the ZTA department responsible for Market Research and New Product Development. The researchers used records from the Ministry of Lands to identify Zimbabwe's five agro-ecological regions. Three regions were selected purposively based on the different agricultural activities, that is, Regions 1 , 2, and 5 . The regions were further divided into districts using multi-stage sampling and one district was purposively chosen for each region. The districts selected were Karoi, Mutare, and Mkwasine districts. The researchers used simple random sampling in the selection of one district per region as the districts in these regions have homogenous characteristics in terms of farming conditions and crops grown.

Purposive sampling was also used to select only those farmers whose farms are actively pursuing agricultural activities. In addition, A1 self-contained farms and A2 farms were targeted as they engage in organised farming with a variety of activities. The communal and the general A1 farms were left out as most of them practice haphazard farming and they mainly concentrate on growing maize only. At ZTA, the key informant technique was used and only one representative from the department of Market Research and New Product Development was targeted. This is because the researchers would benefit more from expert opinion instead of just asking everybody. Hence, a sample size of 267 constituted the respondents in this research.

\section{Data Collection}

A detailed interviewer-administered questionnaire was used to gather data from farmers or farm managers. The questionnaire contained both closed questions and open-ended questions so as to give respondents a chance to give their views and opinions. In addition, the type of questions made the recording, analyzing, and presentation of data easier to the researcher. A thirty-minute interview was conducted with an executive at ZTA's Department of Market Research and New Product Development.

In order to complement the other data collection methods and make the results more valid and reliable, personal observations were also made by the researchers. The researchers, using a predetermined observation guide, observed what was going on at the farms, especially emphasizing on the activities and assets available for agritourism.

\section{Findings and Discussions}

A total of 266 questionnaires were administered to farmers, 1 to ZTA. From the questionnaires administered to farmers, the researchers realised that farmers in Zimbabwe operate different holdings, that is, a farm, ranch, or both. About $63 \%$ of the farmers operate farms where there is intensive crop production. Tree plantations and sugar cane plantations dominate the activities done in Regions 1 and 5 respectively. Few of the farmers, that is, about $8 \%$, operate ranches for cattle and a considerable number of farmers have got mixed operations on their farms.

From the observation made by the researchers, it was concluded that the depth of activities undertaken by farmers is determined by the size of the farm. This is shown in the A2 farms which are fairly larger than the A1 self-contained farms. Farmers sell their produce along high ways and this is a resource for agritourism although the farmers may not be aware of it.

\section{Potential for Agritourism}

The ZTA Department of Market Research and Product Development described the country as offering beautiful tourism products and services to all potential markets. On a scale (from excellent to not sure), the 
country's tourism product was rated as excellent. The National Tourism Office (NTO) agreed that there is a need to develop alternative products to the current product. They indicated that they would offer supportive agritourism policies and regulations, information on tourism markets and trends, establishment of quality standards, and marketing programs in support for development of the concept. The NTO indicated that the country would benefit by generation of more revenue and creation of employment by venturing into agritourism. The responses from the NTO show that the country is in a position to develop alternative products to the current product.

The majority of farmers indicated that they had been in agricultural business for a considerable number of years. This gives the country an advantage when it comes to developing agritourism as the farmers would be well versed with agricultural issues and this would make it easy to merge with tourism. Offering services like educational tours would be easy for farmers. This would be complemented by activities that are already being carried out on the farms which include fishing, fruit harvesting, crop harvesting, roadside stands, and horse riding.

However, crop harvesting is the dominating activity amongst farmers in the country. The other activities that were stated include canoeing, bird viewing, and farm wagon rides by kids. Although these activities are done by the farmers and their friends and families, they can appeal greatly to agritourists as they are components of varying agritourism development themes.

The researchers also observed that some farms that were previously occupied by white people had old disused buildings that were used, for example, as horse stables and granaries and some even have guest houses though they are no longer being used. In addition, those who operate estates are large companies and they have guest houses which may be used for farm accommodation. Most of the current farmers have their own farm houses. This implies that they can be in a position to attract tourists and offer accommodation as the agritourist wants to mix with the locals hence they use local facilities. In addition, the disused buildings can act as attractions to the agritourist.

Related to the above is the issue of agritourism development themes farmers would want to operate. About $69 \%$ of the farmers reiterated that they would want to develop events like farm harvest festivals. The remainder of the farmers stated fixed attractions and recreational services. This shows that if agritourism is to be developed in Zimbabwe, farmers would want to have all the three agritourism development themes. However, the development of these themes would be determined by various factors like size of operation, climatic conditions, and resources like human and financial. For an agritourism operation to be successful, there are some success factors as articulated by Comen and Foster (2002). The researchers gave options of success factors which included location, financial resources, understanding customer needs, ability to match service with customer requirements, passion for learning, strong social skills, creativity, and ability to manage visitor experience. A considerable number of farmers possess more than one of the success skills. This shows that the chances of success if agritourism is promoted are quite high.

In addition to the above factors, farmers stated resources that are already at their operations that would help in developing agritourism. These factors include wildlife, streams, ponds, and livestock. These data show that farmers have the resources that can make agritourism a success although livestock dominated (38\%) and a few have wildlife resources (8\%). This is because most of the wildlife in the country is state property protected in national parks. However, it is important to note that licences can be made available to those who wish to keep game in private game reserves. Other resources that were stated included canals especially in those farms where irrigation is practised like sugarcane plantations and also open spaces that may be ideal for camping. 
The researchers also enquired about the motives for developing agritourism. It was realised that farmers have different motives that include expanding farm operations, improving revenue streams, increasing awareness of local agricultural products, developing entrepreneurial spirit, long-term sustainability of farm business, and maintaining agricultural land sustainability. This shows that motives for venturing into agritourism are diverse ranging from sustainability reasons to improvement of farm revenues. This is supported by Ollenburg and Buckley (2007) who argued that farm tourism provides income for rural landholders facing financial pressures and that it can also have social goals. The range of motives varies from individuals though those who had one motive dominated the results. Farmers also cited some other motives that included employment for family members and strengthening of social ties in the community as they would collectively work together to provide a service to the tourist.

\section{Challenges for Developing Agritourism}

ZTA indicated some challenges that it may face in developing agritourism as an alternative to the current tourism product. The NTO indicated that they would face challenges of inadequate funding to farmers for developing agritourism and lack of infrastructure in rural areas. This means that funds to fully develop the concept can be a problem since the country is facing liquidity problems. This is likely to hamper the successful development of agritourism since some fresh cash injection might be necessary. The training of farmers and farm employing in concepts of hospitality would be very necessary and this requires financial and human resources. The question that remains unanswered is who will meet the costs?

Inadequate and dilapidated infrastructure is another challenge as observed by the researchers. Most farms in the country where agritourism can be practised are difficult to access and this is attributed to the poor state of roads. Most of the roads can be very slippery in rain season of which it is the time when much of the agriculture activities would be happening. In addition, poor communication systems are a problem in most farming areas. These challenges cited by ZTA are common in most developing countries and they are attributed to less priority given to the tourism industry and unequal regional development.

Farmers were given options on the possible challenges that are likely to be faced in an endeavour to develop agritourism. The options included regulations, inadequate financial resources, high cost and availability of insurance, inadequate expertise, taxation, lack of recreation knowledge, lack of information on tourism trends and markets, and lack of family support. Thirty eight percent of the farmers stated that they would face at least four of the challenges and these formed the bulk of the farmers. It was also observed that financial resources were the most cited and the least cited was taxation. It can be concluded that financial resources form the backbone of most new developments. Another factor that was cited by sugarcane farmers is the issue that there is only one customer of the produce hence they are prone to be exploited by being paid little money which would in turn impact on their financial resources.

\section{Possible Ways of Countering the Challenges}

A variety of possible ways to counter the challenges were given by the respondents. ZTA suggested that there is a need to improve on priority given to the industry. This would mean that adequate funds would be availed to the tourism industry. These resources would help with successful development of alternatives to the current tourism product including agritourism in the country. 
Farmers, on the other hand, cited many ways and these included change of the current land tenure system which is a 99-year lease of which all the land belongs to the government. This land tenure system hampers farmers from getting loans from banks as they cannot use the land as collateral. In addition, they cited that banks should relax their requirements in terms of money borrowing so that they can access funds. Related to this was the issue of offering low interest bank loans. Farmers also cited provision of the necessary information on agritourism through awareness programs and training. In addition, they suggested that the government should provide all the necessary support like loosening legal constraints through removing red tape structures.

\section{Conclusions}

Agritourism is a viable possible option for the tourism industry in Zimbabwe. Its success would mean benefits to the tourism industry and to the farmers at large. The resources for the new option are available but the support from the relevant authorities has not been availed. On the other hand, the land tenure is not guaranteed; therefore, farmers are reluctant to put up structures and investments needed for agritourism. This is also exercabated by the uncertainty within the political sphere. The Ministry of Tourism and Hospitality Industry and ZTA need to put forth enabling frameworks to promote this economically viable and socially compatible option.

\section{References}

Agritourism India. (2010). Destination of Maharashtra. Retrieved from http://www.agritourism.in/

Askelli, S. (2005). Agrotouristik guidebook. Kekira Editions. Athens.

Barbieri, C. (2010). An importance-performance analysis of the motivations behind agritourism and other farm enterprise developments in Canada. Journal of Rural and Community Development, 5(1), 1-20.

Beall, G. (1996). Down on the (vacation) farm, small farm center news. Cooperative Extension-UC Davis.

Beri, G. C. (2000). Marketing research (3rd ed.). New Delhi: Tata McGraw-Hill.

Blacka, A., Couture, P., Coale, C., Dooley, J., Hankins, A., Lastovica, A., ..., \& Uysal, M. (2001). Agri-tourism. Retrieved from http://www.pubs.ext.vt.edu/310/310-003/310-003.html

Busby, G., \& Rendle, S. (2000). The transition from tourism on farms to farm tourism. Tourism Management, 21(6), 635-642.

Clarke, J. (1996). Farm accommodation and the communication mix. Tourism Management Journal, 17(8), 611-616.

Colton, J. W., \& Bissix, G. (2005). Developing agritourism in Nova Scotia: Issues and challenges. Journal of Sustainable Agriculture, 27(1), 91-112.

Comen, T., \& Foster, D. (2002). Agricultural diversification and agritourism: Critical success factors. Interim Report Presented to Vermont Department of Agriculture, Food and Markets.

Frater, J. M. (1983). Farm tourism in England: Planning, funding, promotion and some lessons from Europe. Tourism Management, 4(3), 167-179.

Gladstone, J., \& Morris, A. (2000). Farm accommodation and agricultural heritage in Orkney. In F. Brown (Ed.), Tourism in peripheral areas: Case study (pp. 91-100). Clevedon: Multilingual Matters limited.

Gopal, R., Varma, S., \& Gopinathan, R. (2008). Rural tourism development: Constraints and possibilities with a special reference to agri tourism - A case study on agri tourism destination. Paper presented at the Conference on Tourism in India Challenges Ahead (pp. 512-523), May 15-17, IIMK.

Harris, R., Griffin, T., \& Williams, P. (2002). Sustainable tourism: A global perspective. Oxford: Butterworth-Heinemann.

Hegarty, C., \& Przezborska, L. (2005). Rural and agri-tourism as a tool for reorganising rural areas in old and new member states - A comparison study of Ireland and Poland. International Journal of Tourism Research, 7(2), 63-77.

Iakovidou, O. (1997). Agro-tourism in Greece: The case of women agro-tourism co-operatives of Ambelakia. Mediterranean Journal, 8(1), 44-47.

Karambakuwa, R. T., Shonhiwa, T., Murombo, L., Mauchi, F. N., Gopo, N. R., Denhere, W., .., \& Mudavanhu, V. (2011). The impact of Zimbabwe Tourism Authority initiatives on tourist arrivals in Zimbabwe (2008-2009). Journal of Sustainable Development in Africa, 13(6), 68-77. 
Kepe, T., Ntsebeza, L., \& Pithers, L. (2001). Agri-tourism spatial development initiatives in South Africa: Are they enhancing rural livelihoods? Natural Resource Perspectives, 65, 1-4.

Lobo, R. (2001). Helpful agricultural tourism (Agri-tourism) definitions. Retrieved from http://www.sfc.ucdavis.edu/agritourism/definition.html

Maiyaki, A. A. (2010). Zimbabwe’s agricultural industry. African Journal of Business Management, 4(19), 4159-4166.

McCullough, S., Brandt, S., \& Rhoades, S. (2008). Agricultural diversification through agritourism. University of Arkansas, Division of Agriculture, Community and Economic Development.

McGehee, N. G., \& Kim, K. (2004). Motivation for agri-tourism entrepreneurship. Journal of Travel Research, 43(2), 161-170.

Mutisi, C. (2009). Situational analysis of agriculture research and training and support strategies for the national agriculture research system in Zimbabwe. Phase 3 Report.

Nickerson, N. P., Black, R. J., \& McCool, S. F. (2001). Agritourism: Motivations behind farm/ranch business diversification. Journal of Travel Research, 40(1), 19-26.

Nilsson, P. A. (2002). Staying on farms: An ideological background. Annals of Tourism Research, 29(1), 7-24.

Ollenburg, C., \& Buckley, R. (2007). Stated economic and social motivations of farm tourism operators. Journal of Travel Research, 45(4), 444-452.

Pearce, P. L. (1990). Farm tourism in New Zealand: A social situation analysis. Annals of Tourism Research, 17(3), 337-352.

Phillip, S., Hunter, C., \& Blackstock, K. (2010). A typology for defining agritourism. Journal of Tourism Management, 31(6), 754-758.

Pizam, A., \& Poleka, J. (1980). The vacation farm: A new form of tourism destination. In D. E. Hawkins, E. L. Shafer, \& J. M. Rovelstad (Eds.), Tourism marketing and management issues (pp. 203-216). Washington, DC: George Washington University.

Rilla, E. (1997). Unique niches: Agritourism in Britain and New England Marin and Sonoma counties. California: University of California Cooperative Extension.

Roberts, L. (2002). Farm tourism - Its contribution to the economic sustainability of Europe’s countryside. In R. Harris, T. Griffin, \& P. Williams (Eds.), Sustainable tourism - A global perspective. Butterworth-Heinneman.

Schmitt, M. (2010). Agritourism: From additional income to livelihood strategy and rural development. The Open Social Science Journal, 3, 41-50.

Shackley, M. (1993). Guest farms in Namibia: An emerging accommodation sector in Africa's hottest destination. International Journal of Hospitality Management, 12(3), 253-265.

Sharpley, R., \& Sharpley, J. (1997). Rural tourism: An introduction. London: International Thompson Business Press.

Silvia, M. (2008). Some considerations on the agritourism product's quality. Revista Tinerilor Economisti (The Young Economists Journal), 1(10), 64-69.

Sonnino, R. (2004). For a 'piece of bread'? Interpreting sustainable development through agritourism in Southern Tuscany. Sociologia Ruralis, 44(3), 285-300.

Srikatanyoo, N., \& Campiranon, K. (2010). Agritourist needs and motivations: The Chiang Mai case. Journal of Travel \& Tourism Marketing, 27(2), 166-178.

Sznajder, M., Przezborska, L., \& Scrimgeour, F. (2009). Agritourism. London, UK: CABI Publishing.

Travel Industry Association of America [TIAA]. (2004). Outlook for auto travel.

Weaver, D. (2006). Sustainable tourism: Theory and practice. Oxford: Elsevier Limited.

Weaver, D. B., \& Fennell, D. A. (1997). The vacation farm sector in Saskatchewan: A profile of operations. Tourism Management, 18(6), 357-365.

Weiner, D., Moyo, S., Munslow, B., \& O’Keefe, P. (1985). Land use and agricultural productivity in Zimbabwe. Journal of Modern African Studies, 23(2), 251-285.

Williams, P. W., \& Kelly, J. (2001). Cultural wine tourists: Product development considerations for British Columbia's resident wine tourism market. International Journal of Wine Marketing, 13(3), 59-76.

Wilson, S., Fesenmaier, D. R., Fesenmaier, J., \& Van Es, J. C. (2001). Factors for success in rural tourism development. Journal of Travel Research, 40(2), 132-138.

Zimbabwe Tourism Authority [ZTA]. (2007). Zimbabwe: Africa’s Paradise. Harare, Zimbabwe.

Zimbabwe Tourism Authority [ZTA]. (2009). Tourism trends and statistics report. Harare, Zimbabwe.

Zimbabwe Tourism Authority [ZTA]. (2012). Tourism trends and statistics report. Harare, Zimbabwe. 